\title{
Accreted oceanic terranes in Ecuador : Southern edge of the Caribbean plate?
}

\author{
Etienne Jaillard $^{(1,2)}$, Henriette Lapierre ${ }^{(\dagger)}$, Martha Ordoñez ${ }^{(3)}$, \\ Jorge Toro Álava ${ }^{(4)}$, Andrea Amórtegui ${ }^{(2)}$ and Jérémie Vanmelle ${ }^{(2)}$
}

(1) IRD-LMTG, Observatoire Midi-Pyrénées, 14 av. Edouard Belin, 31400 Toulouse, France.

(2) LGCA, Maison des Géosciences, BP 53, 38041 Grenoble Cedex 09, France. Etienne.Jaillard@ujfgrenoble.fr

(3) Petroproducción, CIG-Guayaquil, km 6,5 vía a la Costa, Guayaquil, Ecuador. cigg@telconet.net

(4) Petroproducción, CIG-Quito, av. 6 de Diciembre y G. Cañero, PO Box, 17-01-1006, Quito, Ecuador.

$(\dagger)$ deceased in january 2006.

\section{Abstract}

The western part of Ecuador is made of several oceanic terranes, which comprise two oceanic plateaus, of Early $(\approx 120 \mathrm{Ma})$, and Late Cretaceous age $(\approx 90 \mathrm{Ma})$, respectively. The older oceanic plateau was accreted to the andean margin in the Late Campanian $(\approx 75 \mathrm{Ma})$. Fragments of the Turonian-Coniacian plateau were accreted to the ecuadorian margin in the Late Maastrichtian ( $\approx 68 \mathrm{Ma}$, Guaranda terrane) and Late Paleocene ( $\approx 58$ Ma, PiñonNaranjal terrane). The Guaranda terrane received either fine-grained oceanic sediments of Coniacian-Maastrichtian age, or island arc / back-arc volcanic suites of Middle CampanianMiddle Maastrichtian age. The Piñon-Naranjal terrane recorded a comparable history, completed in the Maastrichtian-Paleocene, either by pelagic cherts, or by island arc products (Macuchi arc).

The Late Cretaceous plateau of Ecuador is interpreted as part of the Caribbean oceanic plateau (COP), because their evolutions are comparable. If so, the COP was not formed by the Galápagos hotspot, but on the Farallon oceanic plate, south of Ecuador and close to the South American margin. The COP belonged to the Farallón plate, until a subduction zone separated both plates in the Middle Campanian, giving way to a well developed Mid Campanian-Mid Maastrichtian island arc. Accretion in the Late Maastrichtian triggered a change in the subduction system, and the development of a new arc system of Late MaastrichtianLate Paleocene age, which crosscut the South America-COP plate boundary. The last accretion occurred in the Late Paleocene.

Although the Andes of South America form a continuous mountain belt and result from processes related to oceanic subduction, the geological evolution varies latitudinally along the chain. The northern Andes differ from the Central Andes, by the lack of manifestations of oceanic subduction between latest Jurassic and Eocene times $(\approx 140-40 \mathrm{Ma})$, and by the presence of magmatic material of oceanic origin in their western part (Gansser 1973; Goossens and Rose 1973). These oceanic units presently constitute the Coast and western Cordillera of Ecuador and Colombia, and are separated from the continental margin by depressions (inter Andean valley of Ecuador), usually filled with Tertiary to Recent deposits, which obscure their geometric relations with the Andean margin (Fig. 1). 


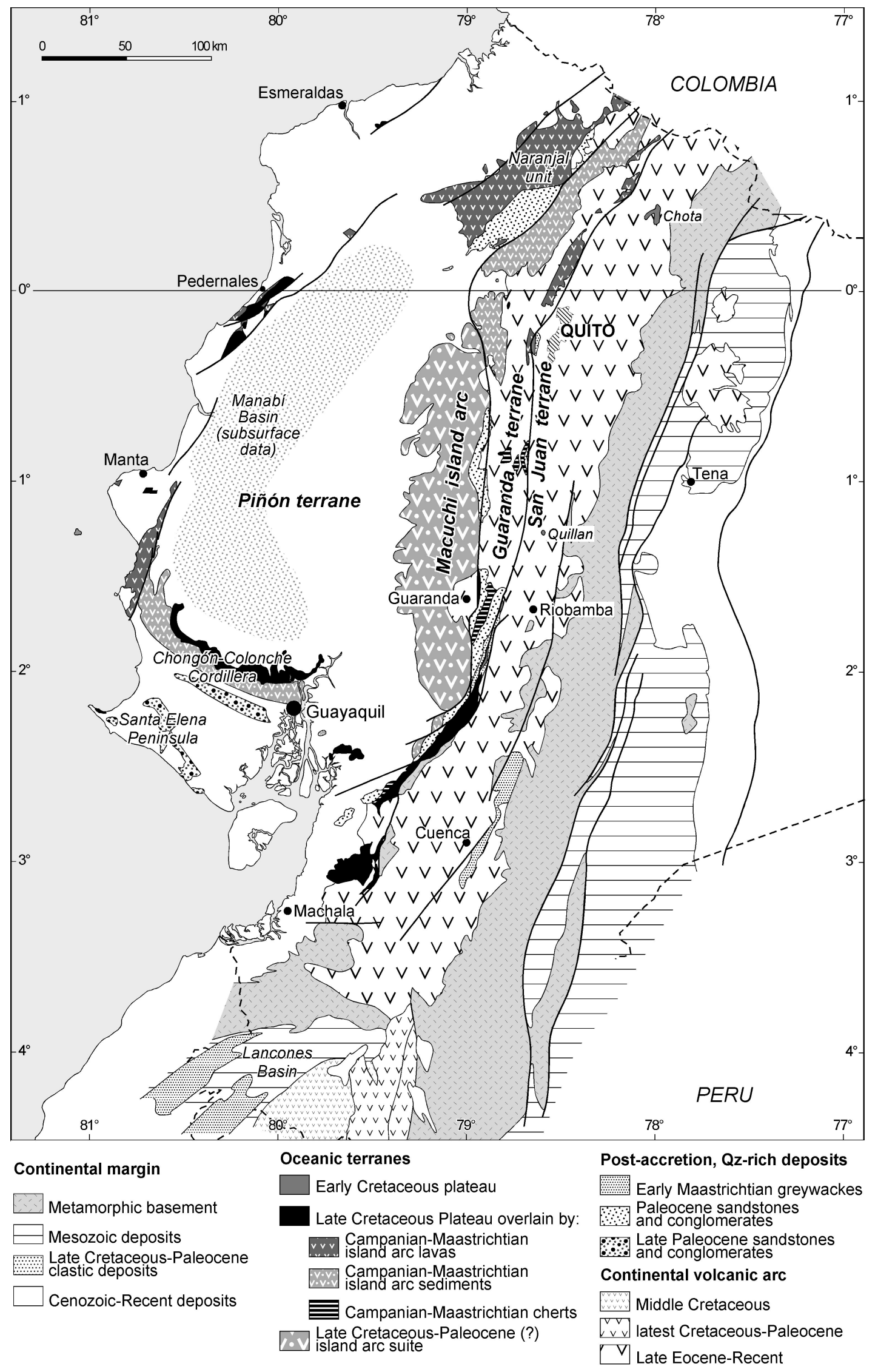

Fig. 1: Geological map of western Ecuador (simplified from Litherland et al. 1994; McCourt et al. 1998; Hughes et al. 1998; Boland et al. 2000; Kerr et al. 2002). 
This oceanic material is widely accepted as representing Cretaceous oceanic terranes, accreted to the Andean continental margin between Late Cretaceous and Eocene times (e.g. Feininger and Bristow 1980; Lebrat et al. 1987; Reynaud et al. 1999; Kerr et al. 2002; Jaillard et al. 2004; Luzieux et al. 2006). Early petrographic and geochemical works on the magmatic basement of western Ecuador allowed to recognise oceanic floor basalts, and island arc basalts and andesites (Kehrer and Van der Kaaden 1979; Egüez 1986; Lebrat et al. 1987; Wallrabe-Adams 1990). In the same way, early workers proposed that accretions occurred in the Campanian, Paleocene, and Eocene (Feininger \& Bristow 1980; Lebrat et al. 1987; Daly 1989; Bourgois et al. 1990).

More recently, detailed geological survey (McCourt et al. 1998; Hughes et al. 1998; Boland et al. 2000; Fig. 1), systematic sampling and analysis of magmatic rocks (Reynaud et al. 1999; Lapierre et al. 2000; Kerr et al. 2002; Mamberti et al. 2003, 2004), associated with radiometric dating (Spikings et al. 2001, 2005; Vallejo et al. 2006) and stratigraphic and sedimentological studies (Jaillard et al. 2004; 2005; Toro \& Jaillard 2005) allowed to recognise several tectonic units and to refine their Late Cretaceous and Paleogene, pre- to post-accretion, evolution. Two oceanic plateaus have been identified, each one overlain by more differenciated lavas and volcaniclastic deposits of island arc affinity (Fig. 1). Stratigraphic studies made us able to reconstruct stratigraphic series for each terrane, and to determine accretionary events in the Late Campanian, Late Maastrichtian, and latest Paleocene.

The aim of this paper is to present an overview of the nature, age, stratigraphy and tectonic setting of the oceanic tectonic units accreted in Ecuador, to describe their Late Cretaceous and Paleogene accretion and tectonic evolution, and to examine the implications of these data on the geodynamic evolution of the eastern Pacific area and the Caribbean Plate.

\section{Oceanic terranes}

\section{San Juan terrane}

The San Juan terrane is the easternmost oceanic unit (eastern part of the Pallatanga terrane of McCourt et al. 1998; Kerr et al. 2002), which crops out along a narrow belt in the western part of the InterAndean valley, and at the eastern border of the Western Cordillera. It yielded a Sm/Nd isochron of $123 \pm 13 \mathrm{Ma}$ (Lapierre et al. 2000) and a poor Ar/Ar integrated age of $105 \mathrm{Ma}$ (Mamberti et al. 2004). These dates may reflect either the age of the oceanic crust, through which the plateau was poored out, or the age of the oceanic plateau itself. The latter interpretation has been preferred until now (Mamberti et al. 2004).

Oceanic rocks. Detailed petrographic and geochemical analysis of the San Juan magmatic rocks has been presented by Mamberti et al. (2004). Along the San Juan section $(20 \mathrm{~km}$ SW of Quito), it comprises mainly ultramafic rocks: peridotites, layered cumulates, and layered and isotropic gabbros. The gabbros and peridotites of the San Juan suite exhibit nearly flat REE patterns, but LREE are slightly enriched in the gabbros, and slightly depleted in the peridotites. Moreover, the latter present very low concentrations $(0,07$ to 3 chondrites $)$. On the basis of the REE pattern, mineralogy, and lithological assemblage of the San Juan section, these rocks have been interpreted as formed in deep magma chambers of an Oceanic plateau (Mamberti et al. 2004). Isolated outcrops along the Interandean Valley of Central (Quillan) and Northern Eciador (Chota) suggest that the San Juan terrane extends eastward below the Interandean valley (Samper and Mollex 2001; Fig. 5). 


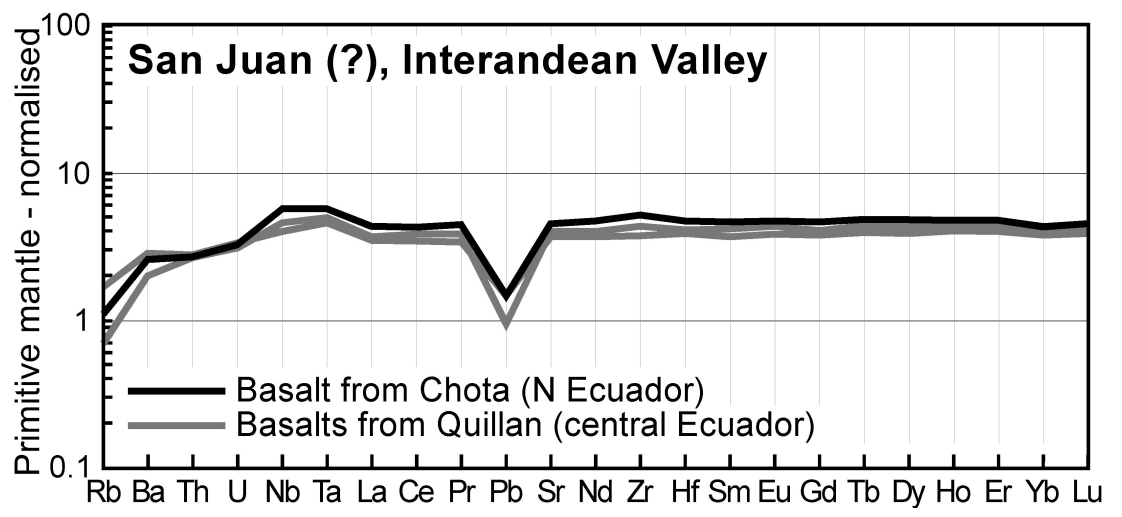

Fig. 5: Multi-element diagram (Sun \& McDonough 1989) for the San Juan (?) oceanic plateau of the Interandean Valley of central (Quillan) and northern (Chota) Ecuador (from Samper and Mollex 2001). Location Fig. 1.

Syn-accretion deposits. The San Juan terrane is tectonically associated with a fine- to medium-grained turbiditic series of a lithic and feldspathic arenites of Early Maastrichtian age (Yunguilla Fm, Bristow \& Hoffstetter 1977; Jaillard et al. 2004; Fig. 2, right), sourced both by volcanic and crystalline areas (Toro \& Jaillard 2005). Although their geometric relations with the San Juan terrane are not visible, these deposits are interpreted as postdating the accretion of the San Juan terrane to the Andean margin, which occurred therefore, in Late Campanian times (Hughes \& Pilatasig 2002; Kerr et al. 2002; Jaillard et al. 2004; 2005). This tectonic event is further documented on the continental margin of southern Ecuador and northern Peru, by the widespread deposition of a coarsening and shallowing upward sequence of conglomerates of Late Campanian age, unconformably overlain by transgressive marine shales of Early Maastrichtian age (Taipe et al. 2004; Jaillard et al. 1999; 2005; Fig. 3).

The Yunguilla Fm is in turn unconformably overlain by a succession of shales and quartz-rich micaceous sandstones of Early to Middle Paleocene age (Saquisilí Fm, Hughes et al. 1998; Toro \& Jaillard 2005; Fig. 2, right).

\section{Guaranda terrane}

The Guaranda terrane (Mamberti et al. 2003; western part of the Pallatanga terrane of McCourt et al. 1998; Kerr et al. 2002) is separated from the San Juan terrane by a major fault (Pujilí Mélange of Hughes \& Pilatasig 2002), and forms the eastern part of the western Cordillera. Although not directly dated, it is overlain by pelagic cherts bearing Santonian to Maastrichtian radiolarians (Boland et al. 2000), thus supporting a Late Cretaceous, pre-Campanian age. 


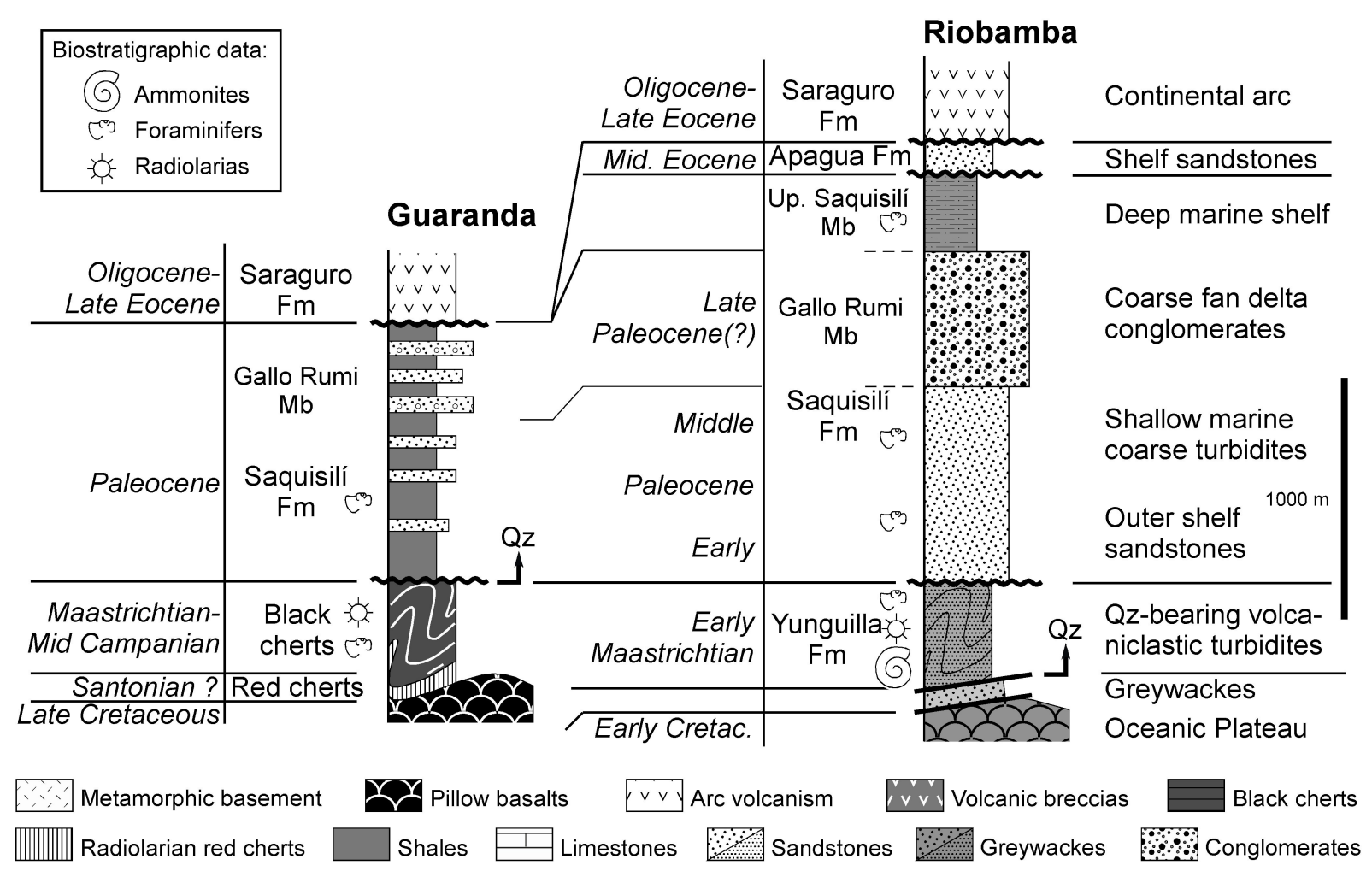

Fig. 2: Stratigraphic successions of the San Juan (right) and Guaranda (left) terranes along the Riobamba-Guaranda section (from Jaillard et al. 2004). Location Fig. 1. Qz : appearance of detrital quartz.

Oceanic evolution. Detailed description of the petrography and geochemistry of the magmatic basement has been made by Mamberti et al. (2003). Besides the hyaloclastites, pillow basalts, dolerites and gabbros that are common to all magmatic basement units, the Guaranda terrane is marked by the frequent occurrence of high-Mg basalts, ankaramites $(8-17 \%$ $\mathrm{MgO}$ ) with large clinopyroxene phenocrysts, and picrites (21-27\% MgO) (Mamberti et al. 2003). Basalts exhibit nearly flat REE plots, while ankaramites are slightly enriched in LREE, and picrites are highly depleted in LREE. All these rocks are interpreted as oceanic plateau basalts originated by a mantle plume (Kerr et al. 2002; Mamberti et al. 2003). Picrites would have been extracted from a depleted mantle source located in the hot plume tail, whereas ankaramites and Mg-rich basalts would have ascended from the less hot edges of the plume (Mamberti et al. 2003).

Since petrographic and geochemical signatures are similar to those of the Caribbean Plate (Kerr et al. 2002; Mamberti et al. 2003), the Guaranda terrane is interpreted as belonging to the Caribbean plate and therefore to have been formed in the Turonian-Coniacian $(\approx$ 92-86 Ma, Sinton et al. 1998), although magmatism in the Caribbean plate lasted at least until the Campanian ( $\approx 75 \mathrm{Ma}$, Mauffret et al. 2001).

The overlying rocks differ in northern and central Ecuador (Fig. 1).

In the Western Cordillera of northern Ecuador, lavas and volcaniclastic products of the Río Cala island arc (Boland et al. 2000; Fig. 6C) are thought to grade laterally into Campanian-Maastrichtian volcaniclastic deposits (Natividad unit, Hughes et al. 1998; Boland et al. 2000; Kerr et al. 2002). Some pillow basalts, associated with red cherts dated by Santonian to Campanian radiolarians, suggest a back-arc basin setting (La Portada unit, Kerr et al. 2002).

In central Ecuador, the oceanic plateau basement is overlain first by red cherts associated with subordinate black bituminous limestones, and then by fine-grained, radiolarian-rich black cherts of Mid Campanian to Maastrichtian age (Jaillard et al. 2004; Fig. 3, left). There- 
fore, the outpouring of the Guaranda oceanic plateau is followed either by island arc development (Río Cala and Naranjal formations, Boland et al. 2000; Fig. 6C) and local back-arc extension (northern Ecuador), or by deposition of autochtonous, siliceous pelagic mudstones without significant volcanic input (central and southern Ecuador).
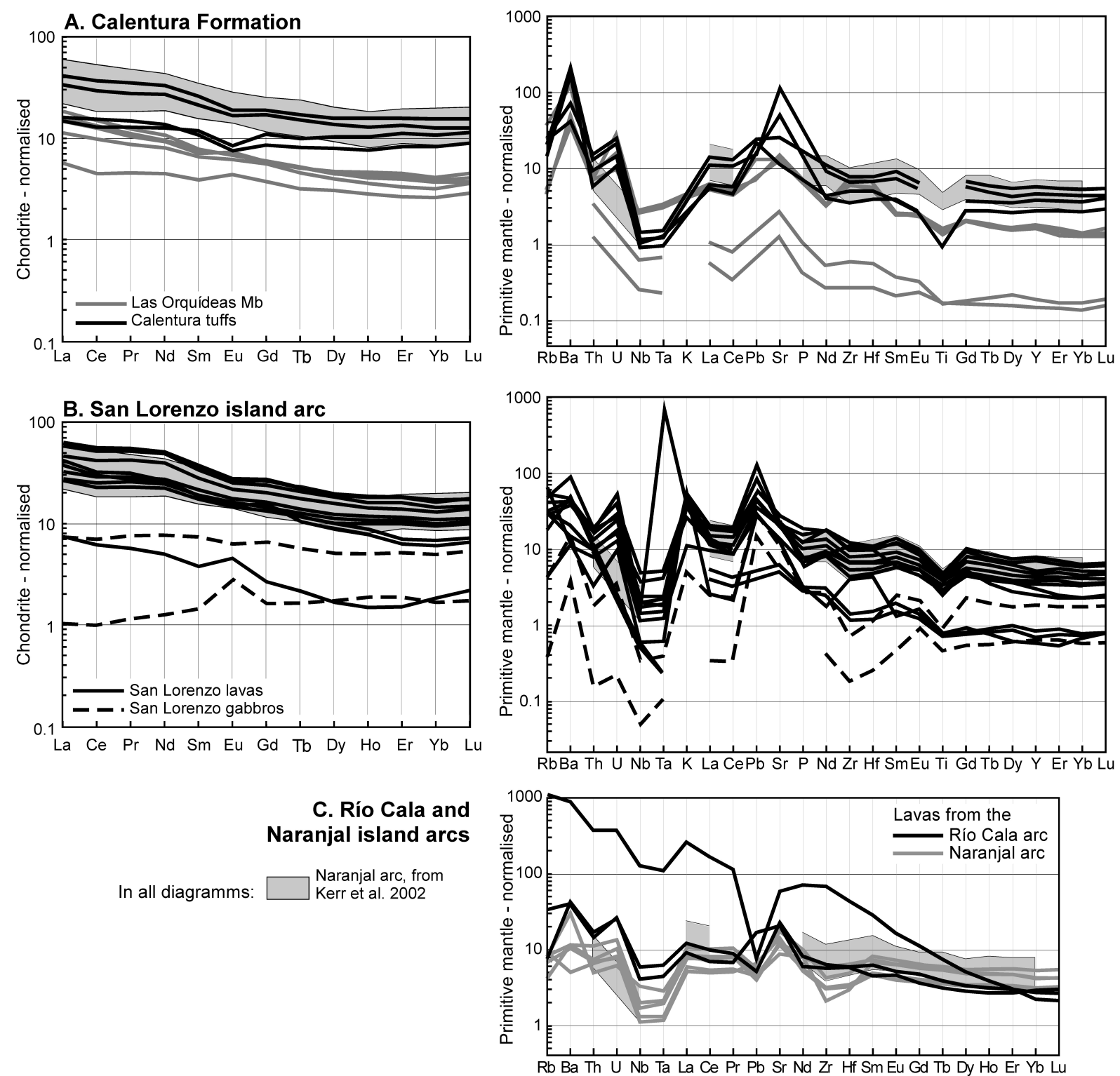

Fig. 6: Rare Earth Element (left) and multi-element (right) diagrams (Sun \& McDonough 1989) for the Calentura Formation of the Guayaquil area (A), the San Lorenzo island arc of the Manta and Pedernales areas (B), and the Rio Cala and Naranjal formations of northwestern Ecuador (C) (from Reynaud et al. 1999; Pourtier 2001; Mamberti 2001; Samper and Mollex 2001; Van Melle 2004).

Syn-accretion deposits. In central Ecuador, the latest Cretaceous oceanic cherts are unconformably overlain by micaceous quartz-sandstones of Early and Middle Paleocene age (Saquisilí Fm, Hughes et al. 1998). The abrupt and massive arrival of detrital quartz on an oceanic succession is interpreted as due to the accretion of the Guaranda terrane, which occurred in the Middle to Late Maastrichtian (Jaillard et al. 2004). The Paleocene succession follows with coarsening-upward conglomerates ascribed to the Late Paleocene (Gallo Rumi $\mathrm{Mb}$ ), deposited in shallow fan deltas in the East or deeper turbidite fans in the West (Toro, 2006). It ends up with fine-grained shales and sandstones of latest Paleocene or Early Eocene 
age (Fig. 3, left). This series is unconformably overlain by transgressive litharenites, of shallow shelf to turbiditic environment, dated as Middle Eocene (Apagua Fm, Egüez 1986; Santos \& Ramírez 1986).

In the Western Cordillera of northern Ecuador, the accretion of the Cretaceous igneous units is postdated by a sharp unconformity at the base of coarse conglomerates of Eocene age, or below transgressive limestones and sandstones of probable Middle Eocene age (Boland et al. 2000). The age of accretion is assumed to be the same as in central Ecuador.

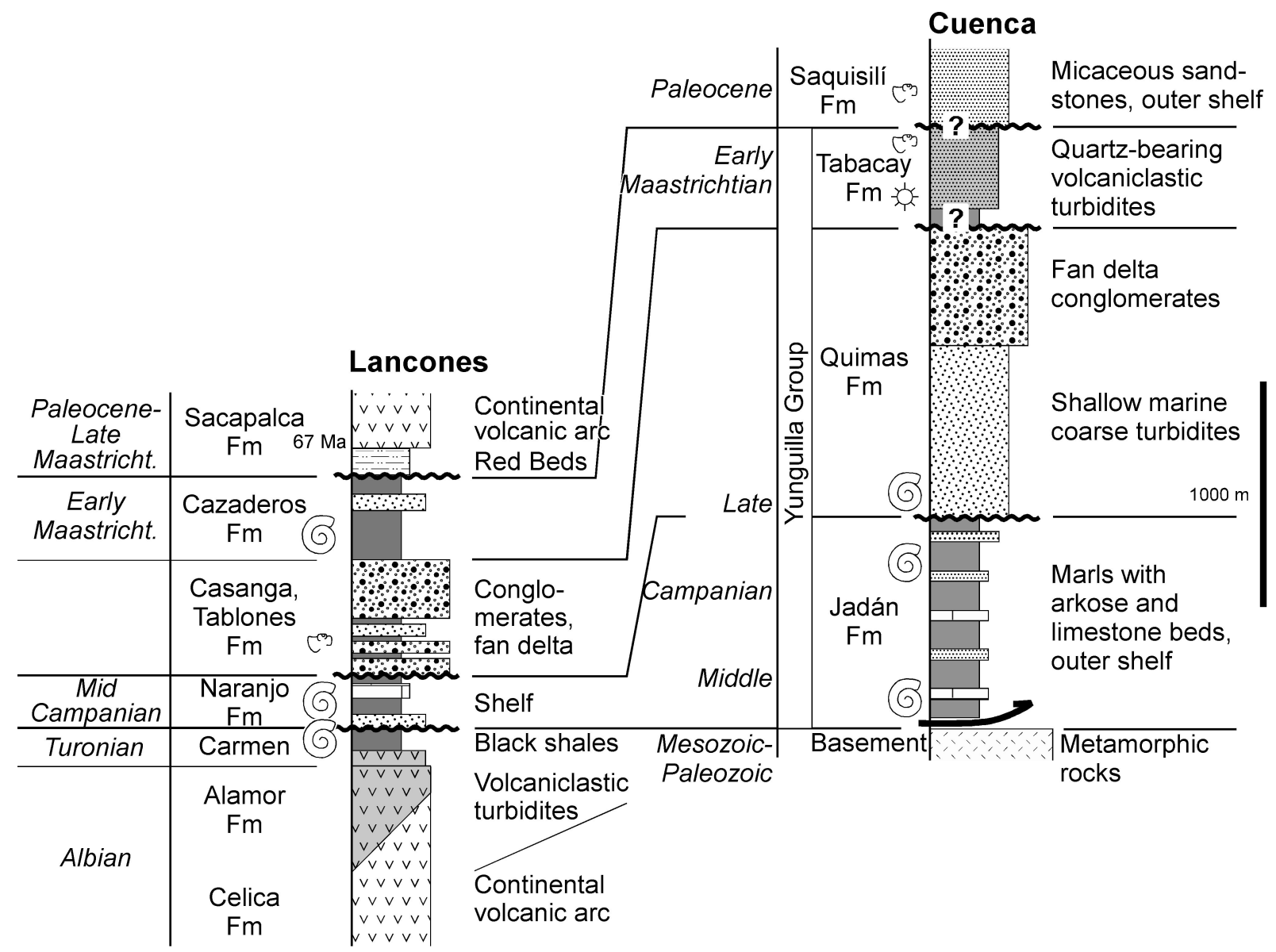

Fig. 3: Stratigraphic successions of the Cuenca and Lancones areas (from Jaillard et al. 1999; 2005). Location Fig. 1; caption Fig. 2; Qz : appearance of detrital quartz.

Farther south, on the continental margin of northern Peru and southern Ecuador, this tectonic event is recorded by a disconformity between Early to Middle Maastrichtian marine shales and sandtones, and Paleocene sandstones (Fig. 3), associated with a well marked hiatus (Taipe et al. 2004; Jaillard et al. 1999; 2005).

\section{Piñón terrane}

In this paper, we will consider that all magmatic outcrops located in the coastal area (Guayaquil, Manta, Pedernales and Esmeraldas areas, Fig. 1) that are not island-arc lavas, belong to the Piñón Formation. We ascribe also the western part of the Western Cordillera of northern Ecuador (part of Naranjal unit of Boland et al. 2000; Naranjal plateau of Kerr et al. 2002) to the Piñón Formation.

Oceanic evolution. The Piñón basement was classically ascribed to the Early Cretaceous (Goossens \& Rose 1973; Jaillard et al. 1995a). It has been recently dated west of Guayaquil, 
where interpillow sediments yielded Coniacian-Campanian radiolarians and foraminifers (Vanmelle et al. in press; Fig. 4, right).
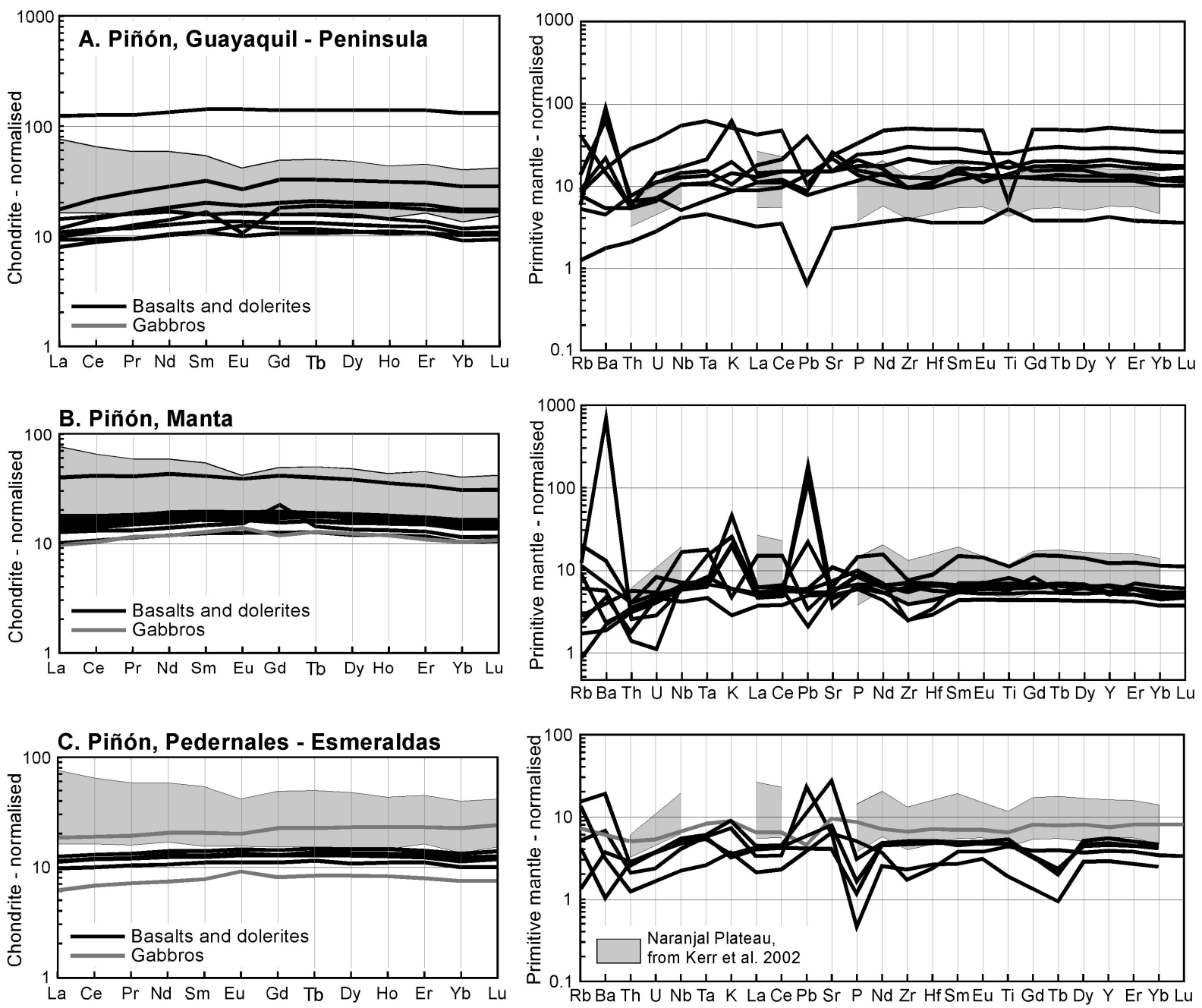

Fig. 7: Rare Earth Element (left) and multi-element (right) diagrams (Sun \& McDonough 1989) for the Piñón oceanic plateau of southern $(A)$, central $(B)$ and northern $(C)$ coastal Ecuador (from Ethien 1999; Pourtier 2001; Van Melle 2004). Location Fig. 1.

The Piñón Formation consists mainly of basalts, pillow basalts, dolerites and small gabbroic intrusions. Basalts are usually marked by low $\mathrm{Si}(<50 \%)$ and $\mathrm{Al}_{2} \mathrm{O}_{3}(13,5-15,8 \%)$ contents, moderate $\mathrm{MgO}(5-9 \%)$, and high $\mathrm{CaO}$ (9-13\%) and $\mathrm{TiO}_{2}(1-2 \%)$ values. Rare Earth Elements plots exhibit a flat pattern, with slight depletion in light REE, typical of Oceanic Plateaux basalts (Reynaud et al. 1999; Pourtier 2001; Fig. 7). Multi-element diagrams exhibit depletion either in HFS (Guayaquil area), or in Large Ionic Lithophile Elements (LILE) (Manta and Pedernales areas, Fig. 7B, 7C). From the Pedernales area, Mamberti (2001) described a Mg-rich (21.2\%) picrite, depleted in $\mathrm{Al}_{2} \mathrm{O}_{3}(10.6 \%)$ and $\mathrm{TiO}_{2}(0.25 \%)$, exhibiting spectacular quenched olivine textures. This rock is geochemically very similar to Gorgona picrites (strong depletion in LREE, very low $\mathrm{Nb}$ and Ta content), thus supporting the idea that some of the Colombian and Ecuadorian terranes belong to the same oceanic plateau. 


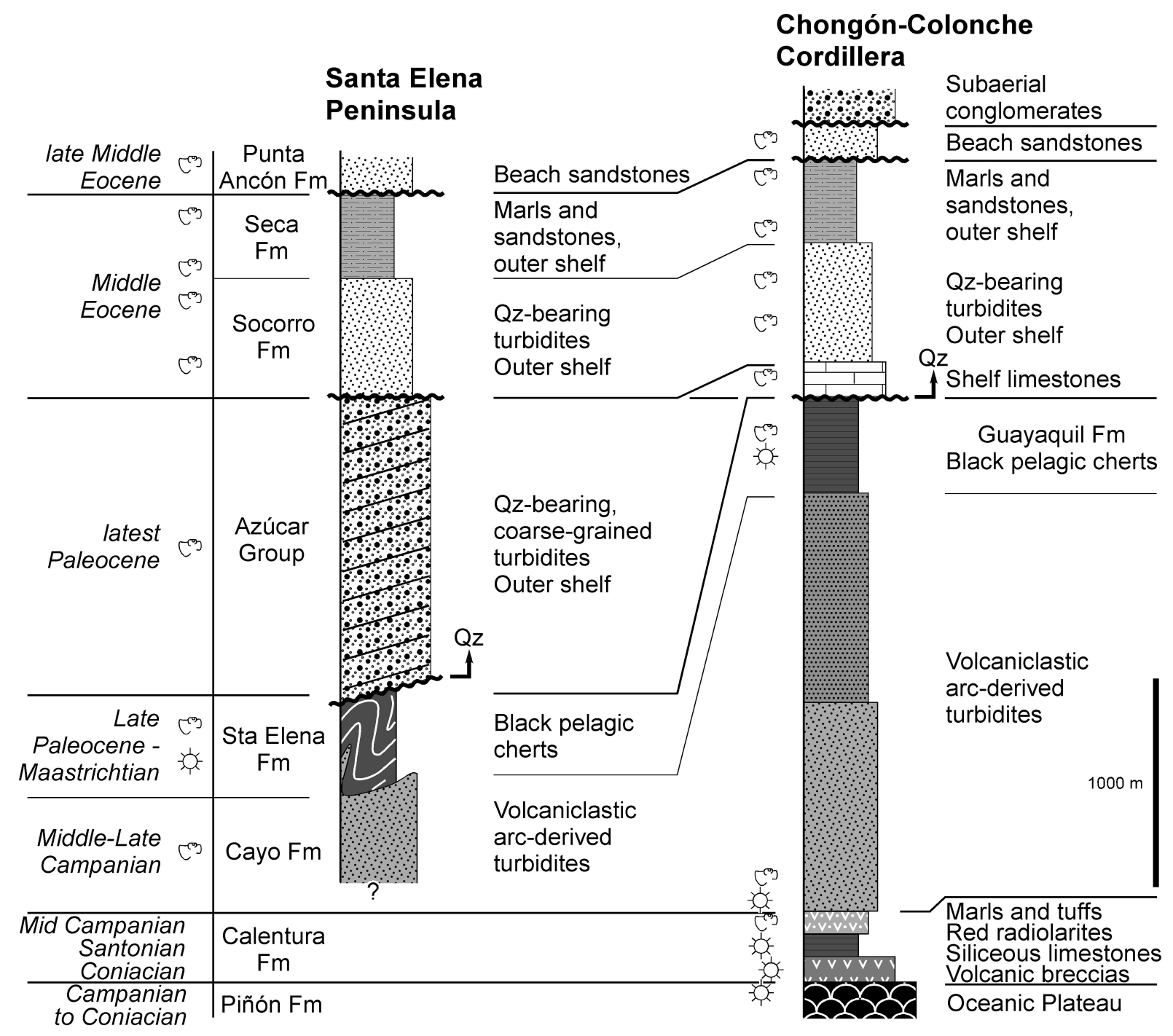

Fig. 4: Stratigraphic successions of the Piñón terrane in southwestern Ecuador (from Jaillard et al. 1995a, Vanmelle et al. in press). Location Fig. 1; caption Fig. 2.

Near Guayaquil, the Piñón basement is overlain by a 30 to $200 \mathrm{~m}$ thick series of andesitic breccias, tuffs, and basaltic lavas (Las Orquídeas Mb, Reynaud et al. 1999; Fig. 6A). Although its geochemical signature is that of a primitive island arc, such a geodynamic setting is unlikely for two main reasons. On one hand, it is difficult to imagine that subduction-related magmatism immediately followed the formation of the Piñon oceanic plateau, since 1 or $2 \mathrm{Ma}$ are necessary before the downgoing slab reaches the magma generation depth. On the other hand, since the overlying deposits do not bear any evidence of arc activity, subduction-related magmatism would have ceased for about $10 \mathrm{Ma}$, before to resume with the development of the Mid Campanian-Maastrichtian island arc $(\approx 80-68 \mathrm{Ma}$, see below $)$. We propose that the Las Orquídeas lavas and breccias might have an origin comparable to that of the arc-like lava quoted by Haase et al. (2005) on the East-Pacific ridge.

This volcanic layer is overlain (Calentura Fm; Fig. 4) first by black siliceous limestones of Coniacian age, and then by undated radiolarian-rich, red siliceous mudstones, probably equivalent to the Santonian-Campanian red mudstones of the Guaranda terrane of northern Ecuador. These are in turn overlain by weldded tuffs and marls of Middle Campanian age (top of Calentura Fm), which grade upward into a thick, coarsening-upward series of volcaniclastic turbidites (Cayo Fm, Fig. 4), the base of which yielded Middle Campanian microfauna 
(Vanmelle et al. in press). These Campanian tuffs and volcaniclastic products exhibit a typical island arc geochemical affinity, more evolved than those of the Las Orquídeas Mb. Farther west, the thick volcaniclastic series grades laterally into pillow basalts, andesites and volcanic breccias of island arc signature (San Lorenzo Fm, Lebrat et al. 1987; Fig. 6B), associated with limestones of Middle Campanian to Middle Maastrichtian age (Jaillard et al. 1995a; Reynaud et al. 1999).

In northern Ecuador, the western part of the Western Cordillera exhibits a magmatic basement with oceanic plateau affinity (Naranjal plateau, Kerr et al. 2002), overlain by lavas and volcaniclastic products of island arc affinity (Naranjal arc, Fig. 6C), which are stratigraphically associated with pelagic oceanic purple-grey siliceous mudstones of Late Campanian-Maastrichtian age (Boland et al. 2000). The Naranjal arc is correlatable with the San Lorenzo Fm of southwestern Ecuador, and with the Ricaurte island arc of southern Colombia (Spadea \& Espinoza 1996).

In the Guayaquil area and west of it, the oceanic sedimentation ends up with finegrained black siliceous cherts of Middle Maastrichtian to Late Paleocene age (Guayaquil Fm, Jaillard et al. 1995a; Keller et al. 1997; Fig. 4, right).

Syn-accretion deposits. Southwest of Guayaquil, the Paleocene pelagic cherts are highly deformed (Santa Elena Fm), and unconformably overlain by a thick succession of coarsegrained, quartz-rich high density turbidites of latest Paleocene age (Azúcar Gp, Jaillard et al. 1995a; Fig. 4, left). This unconformity that emphasizes the arrival of continent-deriving detritism, is interpreted as sealing the accretion of the Piñón terrane to the continental margin. Farther north (Manabí Basin; Fig. 1), Paleocene quartz-rich deposits identified in subsurface data, and resting on Cretaceous magmatic basement (Deniaud 2000), are interpreted in the same way. In the western Cordillera of northern Ecuador, cherts grading upward into massive sandstones of Late Paleocene age (La Cubera Fm, Boland et al. 2000) are regarded as announcing the Eocene accretion (Kerr et al. 2002). We propose that this succession reflects the accretion of the Piñon terrane in the Late Paleocene, as for the whole coastal terrane. On the Guaranda terrane, the Late Paleocene accretionary event is marked by a coarsening upward sequence of high density turbidites (Gallo Rumi Mb, Jaillard et al. 2004).

West of Guayaquil, the Azúcar Gp is in turn folded and unconformably overlain by a classical Middle Eocene forearc sedimentary sequence. The latter comprises from base to top (Fig. 4): diachronic transgressive shelf limestones of latest Early Eocene to early Middle Eocene age, sandstones and turbidites, outer shelf marls of Middle Eocene age, and coarse lithic sandstones of late Middle Eocene (Bartonian) to Late Eocene age (Whittaker 1988; Jaillard et al. 1995a).

\section{Macuchi island arc}

The Macuchi terrane constitutes the western side of the Western Cordillera of central Ecuador (McCourt et al. 1998; Kerr et al. 2002). Although classically ascribed to the Eocene (Egüez 1986; Henderson 1981), it might be older (McCourt et al. 1998; Kerr et al. 2002). The Macuchi terrane remains a poorly understood unit of the Western Cordillera of Ecuador.

Oceanic evolution. This unit consists mainly of volcaniclastic deposits (greywackes, lithic siltstones, volcanic clast-bearing breccias, cherts,...) with intercalations of pillow basalts, andesites, hyaloclastites and tuffs, and intrusions of dolerites and andesites (Egüez 1986; Kerr et al. 2002). Most samples exhibit geochemical signatures of an island arc, with typical Nb, Ta and Ti negative anomalies (Kehrer \& Van der Kaaden 1979; Kerr et al. 2002; Chiaradia et al. 2002; Fig. 8). Some Mg-rich samples may be interpreted either as primitive arc products (Kerr et al. 2002), or as back-arc basin lavas (Hughes et al. 1998). Samples with 
"MORB affinities" mentionned by Lebrat et al. (1987) from the western part of the Macuchi arc probably correspond to rocks from the Guaranda and/or San Juan Oceanic Plateaux.
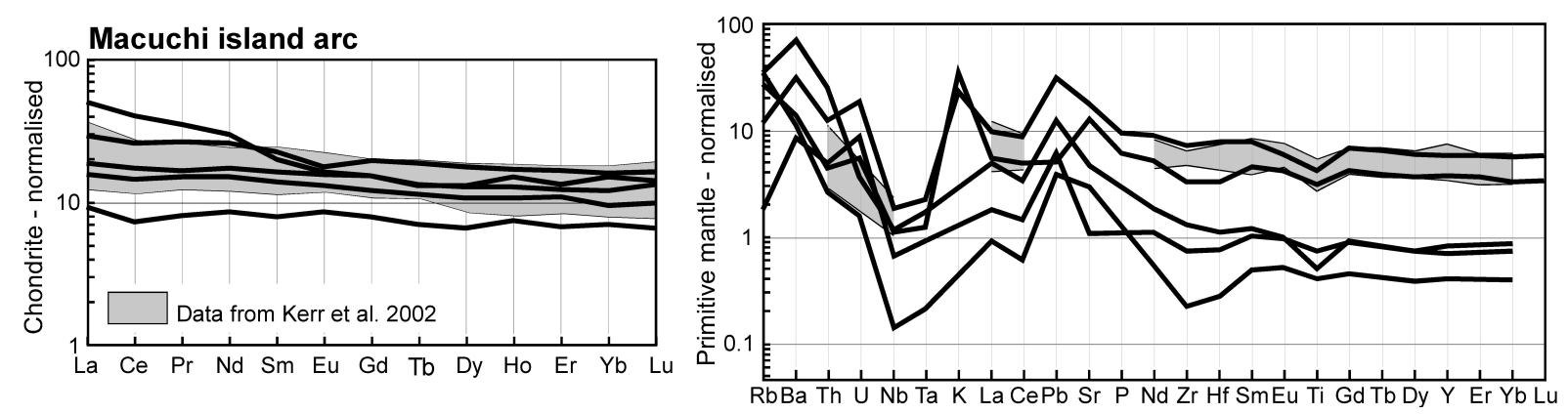

Fig. 8: Rare Earth Element (left) and multi-element (right) diagrams form the Macuchi island arc (from Cosma et al. 1998; Pourtier 2001).

Syn-accretion deposits. The Macuchi magmatic suite is associated with a forearc sedimentary sequence of Middle to Late Eocene age, which comprises from base to top: transgressive shelf limestones (Unacota unit), turbiditic litharenites (Apagua Fm) and fan delta conglomerates (Rumi Cruz Mb; Egüez 1986; Hughes et al. 1998; Toro 2006). Although the contact between these sediments and the Macuchi arc are often tectonised, we consider that the former are the stratigraphic cover of the latter. A comparable sequence is known in the central and northern parts of the Western Cordillera and throughout the coastal area (Fig. 9). Therefore, the Piñón, Naranjal, Macuchi and Guaranda terranes underwent a similar evolution in the Middle Eocene (Santos et al. 1986), indicating that accretions in Ecuador were achieved by Middle Eocene times.

An Eocene age for the Macuchi island arc is therefore unlikely. The Macuchi volcanic arc rocks are overlain by a forearc sedimentary sequence of Middle Eocene age, and yielded a latest Cretaceous FT age (68 $\pm 11 \mathrm{Ma}$, Spikings et al. 2005). They are, therefore, of preMiddle Eocene age, probably of Late Cretaceous to Paleocene age. Furthermore, the Macuchi lavas contain xenoliths of red siliceous cherts similar to those deposited in the SantonianCampanian on the Guaranda and Piñón terranes. This indicates on one hand, that the Macuchi island arc is younger than Early Campanian, and on the other hand, that it overlies a series comparable to that of the Late Cretaceous oceanic plateau of Ecuador. The latter interpretation is supported by the Lead isotopic compositions of the Macuchi island arc lavas, which suggest contamination by a $\mathrm{Pb}$-rich basement, possibly the Caribbean oceanic plateau (Chiaradia et al. 2002; 2004).

Because major changes in the sedimentation (regional disconformities, abrupt appearance of coarse clastics and of lithic component in the detrital input) occurred at the Middle to Late Eocene transition, the Macuchi terrane has been interpreted as accreted at that time (Egüez 1986; Bourgois et al. 1990; Hughes \& Pilatasig 2002). However, the fact that the Middle Eocene transgressive facies are common to all Late Cretaceous accreted oceanic plateau fragments (Santos et al. 1986; Fig. 9), indicates that the accretions were achieved by Middle Eocene times. Moreover, the Macuchi terrane is located between terranes accreted in the Late Mastrichtian to the East, and in the Late Paleocene to the West. As a consequence, unless the western Piñón terrane migrated hundreds of kilometers northward since the Eocene, the Macuchi terrane was necessarily accreted before the latest Paleocene. Note that this would imply that its oceanic evolution had ceased by that times, supporting a pre-Late Paleocene age for the Macuchi island arc.

Therefore, we propose that the Macuchi island arc is of Late Cretaceous to Paleocene age, overlies the Late Cretaceous oceanic plateau, and has been accreted in the Late Paleo- 
cene. In this interpretation, the Macuchi island arc is not a distinct, individualized terrane. It would be coeval with, and would represent a northward extension of, the Maastrichtian-Paleocene Sacapalca arc of southern Ecuador (Jaillard et al. 1996; Hungerbühler et al. 2002; Fig. 1 and 3).

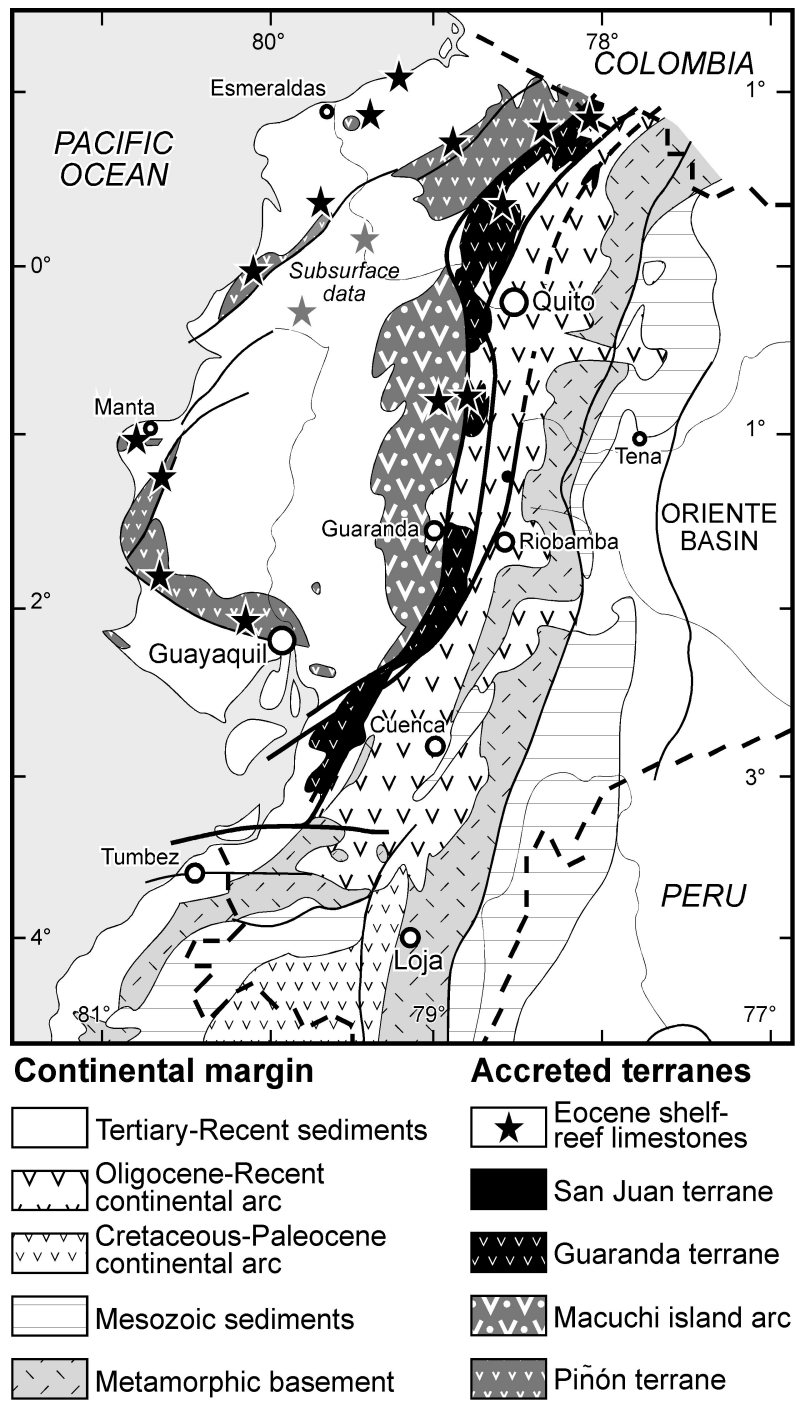

Fig. 9: Distribution of Middle Eocene, trangressive shelf limestones on the accreted terranes (adapted from Santos et al. 1986).

\section{Geodynamic implications}

\section{Preliminary remarks}

The Late Cretaceous oceanic plateau of Ecuador is usually considered as belonging to the Caribbean Oceanic Plateau (COP) (Kerr et al. 1996; 2002; Lapierre et al. 2000). This interpretation is consistent with petrographic, geochemical and radiometric data, as well as with the new stratigraphic data exposed in this paper. However, the Caribbean plate is not restricted to the Caribbean plateau, since the former comprises different magmatic suites of distinct ages (e.g. Donnelly et al. 1990a; Mauffret et al. 2001) and exhibits highly variable crustal structure (Mauffret \& Leroy 1997). Moreover, the nature, age and structure of the Caribbean plate is mainly known by means of field studies of its highly tectonised margins, and few is 
known on the stratigraphy and palaeogeography of the plate as a whole. Therefore, the evolution of the Late Cretaceous oceanic plateau accreted in Ecuador do not necessarily reflects the evolution of the whole Caribbean plate, and cannot be generalised to the latter.

No magmatic arc is known on the Ecuadorian-Colombian continental margin between the Late Jurassic and the Late Eocene ( $\approx 140-40$ Ma; Aspden et al. 1987; Jaillard et al. $1995 b)$. This suggests that no oceanic plate was subducting beneath the NNE-trending margin of the northern Andes during the Cretaceous and Paleocene. Two consequences must be em-

phasized. First, this implies that the accretion of oceanic terranes was not preceded by subduction, and therefore, that the oceanic terranes were not separated from the Andean margin by wide ocanic basins. Second, since subduction did occur beneath the Chilean and Peruvian margins, it can be inferred that the Farallón oceanic plate shifted in a north- to NNE-ward direction during most of the Cretaceous, and that the Ecuadorian-Colombian margin acted mainly as a dextral transform margin. Although speculative, most plate tectonic reconstructions of the Farallón plate motion (Pilger 1984; Pardo-Casas \& Molnar 1987) support the latter intrepretation, since they assume that the Farallón plate shifted northward during latest Cretaceous times at a velocity comprised between 5 and $10 \mathrm{~cm} /$ year, and progressively turned clockwise, until deriving presently in an easterly direction.

Finally, most of the accreted terranes of Ecuador underwent clockwise rotations since the Late Cretaceous, the amount of which varies from 20 to $120^{\circ}$ (Roperch et al. 1987; Luzieux et al. 2006). Therefore, the Cretaceous orientation of the island arcs must be restored through a significant counterclockwise rotation.

\section{Birth place of the COP}

The COP is of Turonian-Coniacian age $(\approx 90 \mathrm{Ma})$ and is overlain by a Mid CampanianMid Maastrichtian island arc $(\approx 80-70 \mathrm{Ma})$, well developped in the coastal area (Cayo-San Lorenzo Fms), and in the northern Western Cordillera (Río Cala, Naranjal arcs). If we accept that the Las Orquídeas volcanics do not represent subduction related magmatism, this means that beween 90 and $80 \mathrm{Ma}$, the COP was erupted through, and belonged to, the Farallón oceanic Plate. The onset of subduction related magmatism in the Middle Campanian $(\approx 80$ Ma) implies that from then on, the COP was separated from the Farallón Plate by a subduction zone, and constituted an individualized tectonic plate.

This, together with the fact that the COP first accreted to the Ecuadorian-Colombian margin in Late Maastrichtian times, implies that the COP was born in the Pacific realm. If we accept that the Farallón plate moved northward before $80 \mathrm{Ma}$, the COP must have formed 500 to $1000 \mathrm{~km}$ south of the latitude of Ecuador. Moreover, since no subduction related magmatism was recorded on the ecuadorian margin before the Late Cretaceous and Paleocene accretions, the COP was located close to the continental margin (Fig. 10).

As a consequence, the COP is likely not to have been originated by the Galápagos hotspot, since the latter was located 2500 to $3000 \mathrm{~km}$ west of Ecuador in the Late Cretaceous (e.g. Scotese et al. 1988; Pindell \& Kennan 2001).

\section{Late Cretaceous - Paleocene evolution of the COP and Ecuadorian margin}

Between 90 and $80 \mathrm{Ma}$, the COP underwent a 500 to $1000 \mathrm{~km}$ shift in a NNW to NE direction, before to be stabilized by the creation of a subduction zone at its southern tip (Fig. 10). At that time, the Farallón plate (and COP) was bounded to the north by a SW-ward subduction zone evidenced by the Late Cretaceous Great Antilles Arc (Pindell et al. 2005). The North- to NE-trending latest Cretaceous San Lorenzo volcanic arc grades eastward into the volcaniclastic turbidites of the Cayo Fm, interpreted as backarc deposits. Taking into account 
the subsequent clockwise rotations, the island arc and associated subduction zone were originally orientated NW-SE to E-W, and most likely located at the southern edge of the Piñón terrane (Fig. 11). The creation of this southern subduction zone may be related to the collision of the northern edge of the COP against the Central American continental blocks (Donnelly et al. 1990b; Iturralde-Vinente 1998; Pindell \& Kennan 2001), and appears grossly coeval with the accretion of the San Juan terrane in Ecuador (Late Campanian, $\approx 75 \mathrm{Ma}$ ). It was associated with a significant colckwise rotation (Roperch et al. 1987; Luzieux et al. 2006).

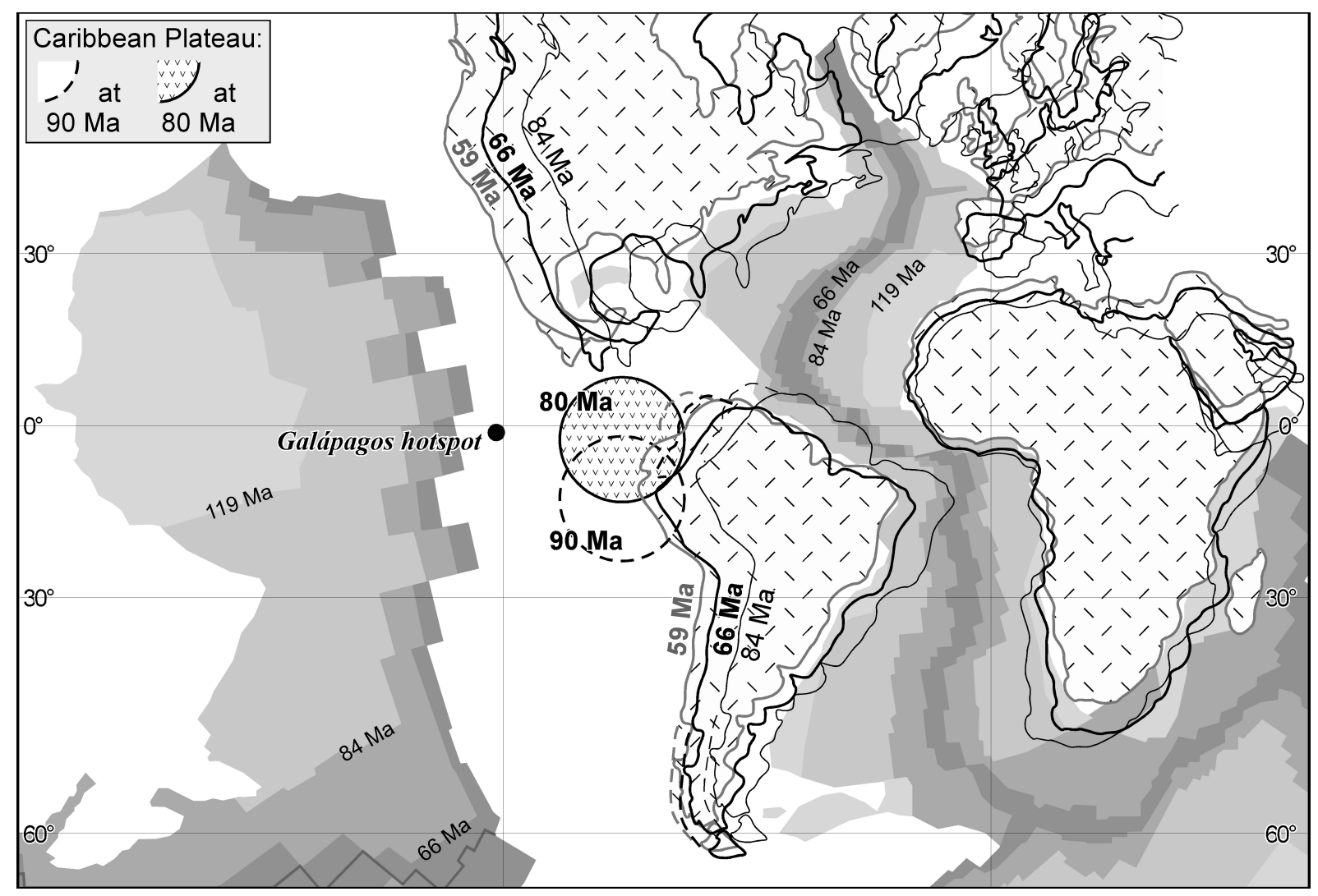

Fig. 10: Proposed evolution of the Late Cretaceous oceanic plateau of Ecuador during Late Cretaceous-Paleocene times. Reconstructed maps are simplified from Scotese et al. (1988). Geometry and age of the oceanic floor correspond to the 59 Ma map.

$90 \mathrm{Ma}$ : Formation of the COP SW of Ecuador; $80 \mathrm{Ma}$ : Creation of a subduction zone south of the COP, probably due to collision with Central America, allowing development of the CampanianMaastrichtian island arcs; 66 and 59 Ma: ongoing collision/accretion of the COP to northern South America.

The accretion of the Guaranda terrane occurred in the Late Maastrichtian $(\approx 68 \mathrm{Ma}$; Fig. 11). As for the Late Campanian accretionary event, the Late Maastrichtian tectonic event is known all around the Caribbean area, and is coeval with the collision of the COP in Central America (Maya block; Donnelly et al. 1990b) and Cuba (Iturralde-Vinente 1998). Like for the Late Campanian tectonic event, this accretionary event seems to have been followed by a reorganization of the subduction zones. We propose that the resumption of arc magmatism on the continental margin of southern Ecuador (Sacapalca Arc, Hungerbühler et al. 2002; Fig. 1 and 3) was coeval with the development of the Macuchi island arc, on the not yet accreted Piñon-Naranjal oceanic terrane, and reflects a new subduction geometry. Since accretion was associated with clockwise rotation (Roperch et al. 1987; Luzieux et al. 2006), the new, Paleogene arc is oblique to the Late Creaceous island arc (Fig. 11). This suggests that subduction, 
which was already occurring in northern Peru, became possible farther north, possibly because of the NE-ward shift of the COP (Pindell et al. 2005).
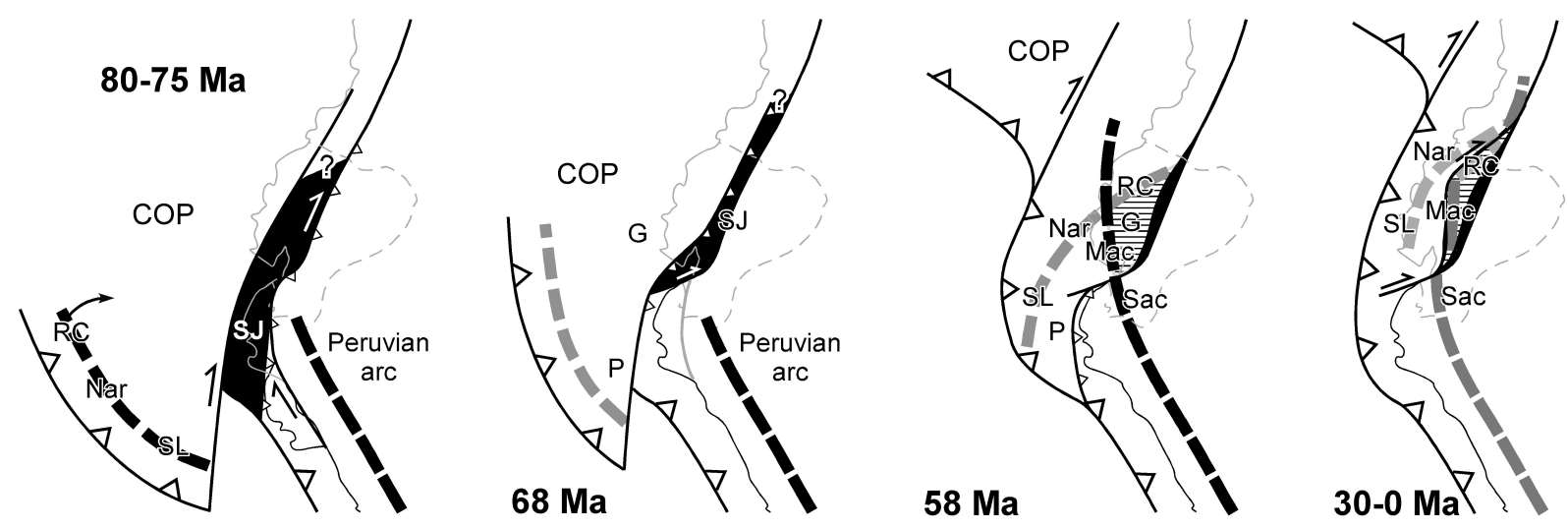

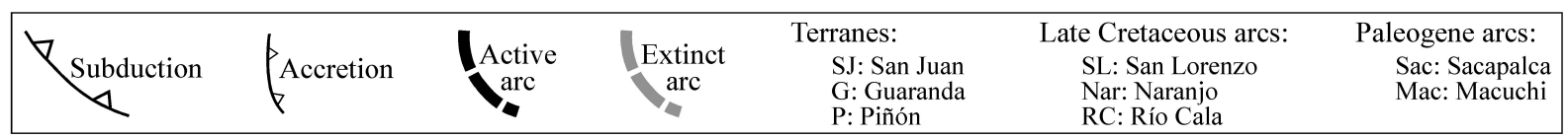

Fig. 11: A possible scenario for successive accretions in Ecuador.

Late Campanian (80-75 Ma): Collision of the COP with Mexico creates a subduction and related arc south of the COP; accretion of San Juan terrane against the Andean margin.

Late Maastrichtian (68 Ma): Accretion of Guaranda terrane, development of a Paleogene arc.

Late Paleocene (58 Ma): Accretion of Piñón terrane, dextral movements along the sutures.

Neogene ( $\approx 30-0$ Ma): Ongoing dextral movements, development of a Neogene arc (not drawn) superimposed to former ones.

The Piñón terrane, last fragment of the COP, was accreted to the Ecuadorian margin in the Late Paleocene ( $\approx 58 \mathrm{Ma}$; Fig. 11$)$. Two interpretations must be discussed.

First, part of the COP was still located at $3^{\circ}$ lat. S at that time, or even $5^{\circ}$ lat. S (Pécora et al. 1999), and accreted to the margin. As the COP is assumed to have collided with the north American plate in Cuba $\left(\approx 23^{\circ}\right.$ lat. N.) in the Late Maastrichtian, this would imply that the COP was about $3000 \mathrm{~km}$ long. However, the presence of an arc as early as the Late Maastrichtian in southern and central Ecuador implies that subduction already occurred beneath the paleo-ecuadorian margin, and therefore, that the COP shifted farther north (Fig. 11).

In a second interpretation, the formerly accreted COP fragment has been splitted into an eastern (Guaranda) terrane, and a western (Pinón) terrane, the latter being underthrusted beneath the former; this implies that the COP had been teared into several tectonic slices, probably bounded by NNE- to NE-trending dextral faults (Fig. 11). The Guayaquil, Manta-Naranjal, and Pedernales-Esmeraldas areas may represent such tectonic slices, since they are separated from each other by important NE-trending faults (Fig. 1), their magmatic basement present distinct petrographic features, their deformation styles differ, and their stratigraphic successions are comparable but slightly different.

In our interpretation, no accretion occurred in Ecuador during the Middle to Late Eocene time-span. The compressional deformations recorded at that time in Ecuador are more likely related to the Incaic phase, kown at this time in the whole Andean domain (Steinmann 1929; Mégard 1984; Jaillard et al. 2000). 


\section{Summary and conclusions}

Three main oceanic terranes can be identified in Ecuador, which were accreted between Late Campanian and Late Paleocene times. (1) The San Juan terrane is made of an Early Cretaceous oceanic plateau, accreted in the Late Campanian $(\approx 75 \mathrm{Ma})$. (2) The Guaranda terrane is made a Coniacian oceanic plateau $(\approx 90 \mathrm{Ma})$, overlain by either CampanianMaastrichtian island arc products, or Santonian-Maastrichtian pelagic cherts, which was accreted in the Late Maastrichtian ( $\approx 68 \mathrm{Ma})$. (3) The Piñón-Naranjal terrane also comprises a Late Cretaceous oceanic plateau overlain by Late Cretaceous island arc suites, and accreted in the Late Paleocene $(\approx 58 \mathrm{Ma})$. We propose that the Macuchi island arc rests on the PiñonNaranjal oceanic plateau, is of Late Maastrichtian-Late Palaleocene age, and was accreted to the composite Andean margin in the Late Paleocene.

The Late Cretaceous oceanic plateau of Ecuador was formed on the Farallón Plate, south of Ecuador and close to the South American plate. It shifted 500 to $1000 \mathrm{~km}$ northward before to be separated from the Farallón Plate by a north-dipping subduction zone in the Middle Campanian. Then, a fragment of this newly formed oceanic plate collided to the Ecuadorian margin in the Late Maastrichtian, inducing a re-organisation of the subduction zones and the development of a new arc system (Sacapalca-Macuchi). New fragments of the COP were accreted to the ecuadorian margin in the Late Paleocene. This scenario is compatible with the idea according to which the Late Cretaceous oceanic plateau of Ecuador belonged to the Caribbean plate, provided that this plate was rather large $(\approx 3000 \mathrm{~km})$, and splitted into several fragments during its accretionary history.

\section{Acknowledgements}

This paper is dedicated to Prof. Henriette Lapierre, who died abruptly in january 2006, after having worked on magmatic rocks of Ecuador for more than 10 years. We are indebted to A. Dhondt, P. Bengtson, N. Jiménez and J. Suárez for numerous paleontological determinations. Most of the results presented here were obtained thanks to the financial support of the Institut de Recherche pour le Développement (IRD), and the DyETI funding program.

\section{References}

ASPDEN, J.A., McCOURT, W.J. \& BROOK, M. 1987. Geometrical control of subduction-related magmatism: the Mesozoic and Cenozoic plutonic history of Western Colombia. Journal of the geological Society, London, 144, 893-905.

BOLAND, M.P., McCOURT, W.J. \& BEATE, B. 2000. Mapa geológico de la Cordillera Occidental del Ecuador entre $0^{\circ}-1^{\circ} \mathrm{N}$, escala $1 / 200.000$. Ministerio de Energía y Minas-BGS publs., Quito.

BOURGOIS, J., EGÜEZ, A., BUTTERLIN, J. \& DE WEVER, P. 1990. Evolution géodynamique de la Cordillère Occidentale des Andes d'Equateur : la découverte de la formation éocène d'Apagua. Comptes Rendus à l'Académie des Sciences, Paris, (II), 311, 173-180.

BRISTOW, C.R. \& HOFFSTETTER, R. 1977. Ecuador. Lexique Stratigraphique International, V, 5a2, 410 p., CNRS publ., Paris.

CHIARADIA, M. \& FONTBOTÉ, L. 2002. Lead isotope systematics of Late Cretaceous - Tertiary Andean arc magmas and associated ores between $8^{\circ} \mathrm{N}$ and $40^{\circ} \mathrm{S}$ : evidence for latitudinal mantle heterogeneity beneath the Andes. Terra Nova, 14, 337-342.

CHIARADIA, M., FONTBOTE, L. \& BEATE, B. 2004. Cenozoic continental arc magmatism and associated mineralization in Ecuador. Mineralium Deposita, 39, 204-222.

COSMA, L., LAPIERRE, H., JAILLARD, É., LAUBACHER, G., BOSCH, D., DESMET, A., MAMBERTI, M. \& GABRIELE, P. 1998. Pétrographie et géochimie de la Cordillère Occidentale du Nord de l'Équateur $\left(0^{\circ} 30^{\prime} \mathrm{S}\right)$ : Implications tectoniques. Bulletin de la Société géologique de France, 169, 739-751. 
DALY, M.C. 1989. Correlations between Nazca/Farallón plate kinematics and Forearc basin evolution in Ecuador. Tectonics, 8, 769-790,

DENIAUD, Y. 2000. Enregistrement sédimentaire et structural de l'évolution géodynamique des Andes équatoriennes au cours du Néogène : étude des bassins d'avant-arc et bilans de masse. Géologie Alpine, Mémoire, 32, $157 \mathrm{pp}$.

DONNELLY, T.W., BEETS, D., CARR, M.J., JACKSON, T., KLAVER, G., LEWIS, J., MAURY, R., SCHELLEKENS, H., SMITH, A.L., WADGE, G. \& WESTERCAMP, D. 1990a. History and tectonic setting of Caribbean magmatism. In: DENGO, G. \& CASE, J.E. (eds) The Caribbean region, The Geology of Northern America, vol. H, 339-374, Geological Society of America.

DONNELLY, T.W., HORNE, G.S., FINCH, R.C. \& LÓPEZ-RAMOS, E. 1990b. Northern Central America: the Maya and Chortis blocks. In: DENGO, G. \& CASE, J.E. (eds) The Caribbean region, The Geology of Northern America, vol. H, 37-76, Geological Society of America.

EGÜEZ, A. 1986. Evolution Cénozoïque de la Cordillère Occidentale septentrionale d'Equateur $\left(0^{\circ} 15^{\prime} \mathrm{S}-1^{\circ} 10^{\prime} \mathrm{S}\right)$ : les minéralisations associées. Unpublished thesis University Paris VI, 116 p., Paris.

ETHIEN, R. 1999. Pétrologie, minéralogie et géochimie de basaltes et dolérites crétacés à affinités de Plateau Océanique d'Équateur Occidental. Unpublished maîtrise memoir, Univ. Grenoble I, 39 pp..

FEININGER, T. \& BRISTOW, C.R. 1980. Cretaceous and Paleogene history of coastal Ecuador. Geologische Rundschau, 69, 849-874.

GANSSER, A. 1973. Facts and Theories on the Andes. Journal of the geological Society, London, 129, 93-131.

GOOSSENS, P.J. \& ROSE, W.I. 1973. Chemical composition and age determination of tholeitic rocks in the basic Cretaceous Complex, Ecuador. Geological Society of America Bulletin, 84, 1043-1052.

HAASE, K.M., STRONCIK, N.A., HÉKINIAN, R. \& STOFFERS, P. 2005. Nb-depleted andesites from the Pacific-Antarctic Rise as analogs for early continental crust. Geology, 33, 921-924.

HENDERSON, W.G. 1981. The volcanic Macuchi Formation, Andes of Northern Ecuador. Newsletters on Stratigraphy, 9, 157-168.

HUGHES, R.A., BERMUDEZ, R. \& ESPINEL, G. 1998. Mapa geológico de la Cordillera Occidental del Ecuador entre $0^{\circ}-1^{\circ} \mathrm{S}$, escala 1:200.000. CODIGEM-Ministerio de Energía y Minas-BGS publs., Quito, Nottingham.

HUGHES, R.A. \& PILATASIG, L.F. 2002. Cretaceous and Tertiary terrane accretion in the Cordillera Occidental of the Andes of Ecuador. Tectonophysics, 345, 29-48.

HUNGERBÜHLER, D., STEINMANN, M., WINKLER, W., SEWARD, D., EGÜEZ, A., PETERSON, D.E., ELG, U. \& HAMMER, C. 2002. Neogene stratigraphy and Andean geodynamics of southern Ecuador. Earth Science Reviews, 57, 75-124.

ITURRALDE-VINENTE, M.A. 1998. Sinopsis de la constitución geológica de Cuba. Acta Geologica Hispanica, 33, 9-56.

JAILLARD, E., ORDOÑEZ, M., BENÍTEZ, S., BERRONES, G., JIMÉNEZ, N., MONTENEGRO, G. \& ZAMBRANO, I. 1995a. Basin development in an accretionary, oceanic-floored forearc setting : southern coastal Ecuador during late Cretaceous to late Eocene times. In: TANKARD, A.J., SUÁREZ, R. \& WELSINK, H.J. (eds), Petroleum Basins of South America. American Association of Petroleum Geologists, Memoir, 62, 615631.

JAILLARD, É., SEMPÉRÉ, T., SOLER, P., CARLIER, G. \& MAROCCO, R. 1995b. The role of Tethys in the evolution of the Northern Andes between Late Permian and Late Eocene times. In: NAIRN, A.E.M., RICOU, L.-E., VRIELYNK, B. \& DERCOURT, J. (eds) The Tethys Ocean. Ocean basins and margins, vol. 8, 463492, Plenum Press, New York.

JAILLARD, É., HÉRAIL, G., MONFRET, T., DÍAZ-MARTÍNEZ, E., BABY, P., LAVENU, A. \& DUMONT, J.-F. 2000. Tectonic evolution of the Andes of Ecuador, Peru, Bolivia and northernmost Chile. In: CORDANI, U.G., MILANI, E.J., THOMAZ, F., CAMPOS, D.A. (eds) Tectonic evolution of South America. 481559, Publication of the 31st International Geological Congress, Rio de Janeiro.

JAILLARD, É., LAUBACHER, G., BENGTSON, P., DHONDT, A. \& BULOT, L. 1999. Stratigraphy and evolution of the Cretaceous forearc "Celica-Lancones Basin" of Southwestern Ecuador. Journal of South American Earth Sciences, 12, 51-68.

JAILLARD, E., ORDOÑEZ, M., SUÁREZ, J., TORO, J., IZA, D. \& LUGO, W. 2004. Stratigraphy of the Late Cretaceous-Paleogene deposits of the Western Cordillera of Central Ecuador: Geodynamic implications. Journal of South American Earth Sciences, 17, 49-58.

JAILLARD, É., BENGTSON, P. \& DHONDT, A. 2005. Late Cretaceous marine transgressions in Ecuador and northern Peru: a refined stratigraphic framework. Journal of South American Earth Sciences, 19, 307-323.

KEHRER, W. \& VAN der KAADEN, G. 1979. Notes on the Geology of Ecuador with special reference to the Western Cordillera. Geologische Jahrbuch, B 35, 5-57. 
KELlER, G., ADATTE, T., HOLLIS, C., ORDOÑEZ, M., ZAMBRANO, I., JÍMENEZ, N., STINNES-BECK, W., ALEMÁN, A. \& HALE-ERLICH, W. 1997. The Cretaceous-Tertiary boundary event in Ecuador: reduced biotic effects due to eastern boundary current setting. Marine Micropaleontology, 31, 97-133.

KERR, A.C., TARNEY, J., MARRINER, G.F., NIVIA, A. \& SAUNDERS, A.D. 1996. The geochemistry and tectonic setting of Late Cretaceous Caribbean and Colombian volcanism. Journal of South American Earth Sciences, 9, 111-120.

KERR, A.C., ASPDEN, J.A., TARNEY, J. \& PILATASIG, L.F., 2002. The nature and provenance of accreted terranes in Western Ecuador: Geochemical and tectonic constraints. Journal of the Geological Society, London, 159, 577-594.

LAPIERRE, H., BOSCH, D., DUPUIS, V., POLVÉ, M., MAURY, R.C., HERNANDEZ, J., MONIÉ, P., YÉGHICHEYAN, D., JAILLARD, É., TARDY, M., MERCIER de LÉPINAY, B., MAMBERTI, M., DESMET, A., KELLER, F. \& SÉNEBIER, F. 2000. Multiple Plume Events in the genesis of the peri-Caribbean Cretaceous Oceanic Plateau Province. Journal of Geophysical Research, 105, 8403-8421.

LEBRAS, M., MEGARD, F., JUTEAU, T. \& CALLE, J. 1985. Pre-orogenic assemblages and structure in the Western Cordillera of Ecuador between $1^{\circ} 40^{\prime} \mathrm{S}$ and $2^{\circ} 20^{\prime} \mathrm{S}$. Geologische Rundschau, 74, 343-351.

LEBRAT, M., MEGARD, F., DUPUY, C. \& DOSTAL, J. 1987. Geochemistry and tectonic setting of pre-collision Cretaceous and Paleogene volcanic rocks of Ecuador. Geological Society of America Bulletin, 99, 569578.

LITHERLAND, M., ZAMORA, A., EGÜEZ, A., ASPDEN, J., BAEZ, N., BEATE, B., BENÍTEZ, S., JAILLARD, É. \& VAN THOURNOUT, F. 1993. Mapa geológico de la República del Ecuador, escala 1:1,000,000. Geological Survey Publ., Keyworth, UK.

LUZIEUX, L., HELLER, F., SPIKINGS, R., VALLEJO, C. \& WINKLER, W. 2006. Origin and Cretaceous history of the coastal Ecuadorian forearc between $1^{\circ} \mathrm{N}$ and $3^{\circ} \mathrm{S}$ : paleomagnetic, radiometric and fossil evidence. Earth and Planetary Science Letters, 249, 400-414.

MAMBERTI, M. 2001. Origin and evolution of two Cretaceous oceanic plateaus accreted in Western Ecuador (South America), evidenced by petrology, geochemistry and isotopic chemistry. Thesis Universities of Lausanne-Grenoble, $267 \mathrm{pp}$.

MAMBERTI, M., LAPIERRE, H., BOSCH, D., ETHIEN, R., JAILLARD, É., HERNANDEZ, J. \& POLVÉ, M. 2003. Accreted fragments of the Late Cretaceous Caribbean-Colombian Plateau in Ecuador. Lithos, 66, 173199.

MAMBERTI, M., LAPIERRE, H., BOSCH, D., JAILlARD, É., HERNANDEZ, J. \& POLVE, M. 2004. The Early Cretaceous San Juan plutonic suite, Ecuador: a magma chamber in an Oceanic Plateau. Canadian Journal of Earth Sciences, 41, 1237-1258.

MAUFFRET, A. \& LEROY, S. 1997. Seismic stratigraphy and structure of the Caribbean igneous province. Tectonophysics, 283, 61-104.

MAUFFRET, A., LEROY, S., VILA, J.-M., HALLOT, E., MERCIER DE LEPINAY, B. \& DUNCAN, R.A. 2001. Prolonged magmatic and tectonic development of the Caribbean Igneous Provience revealed by a diving submersible survey. Marine Geophysical Researches, 22, 17-45.

McCOURT, W.J., DUQUE, P., PILATASIG, L.F. and VILLAGÓMEZ, R. 1998. Mapa geológico de la Cordillera Occidental del Ecuador entre $1^{\circ}-2^{\circ}$ S., escala 1/200.000. CODIGEM-Min. Energ. Min.-BGS publs., Quito.

MÉGARD, F. 1984. The Andean orogenic period and its major structures in Central and Northern Peru. Journal of the Geological Society of London, 141, 893-900.

PARDO-CASAS, F. \& MOLNAR, P. 1987. Relative motion of the Nazca (Farallón) and South America plate since late Cretaceous times. Tectonics, 6, 233-248.

PÉCORA, L., JAILLARD, É. \& LAPIERRE, H. 1999. Accrétion paléogène et décrochement dextre d'un terrain océanique dans le Nord du Pérou. Comptes Rendus de l'Académie des Sciences, Paris, Earth Planetary Sciences, 329, 389-396.

PILGER, R.H. Jr. 1984 Cenozoic plate kinematics, subduction and magmatism. Journal of the geological Society of London, 141, 793-802.

PINDELL, J.L. \& KENNAN, L. 2001. Kinematic evolution of the Gulf of Mexico and Caribbean. In: Petroleum systems of deep-water basins: Global and Gulf of Mexico experience, SEPM Gulf Coast Section, Proceedings of the $21^{\text {st }}$ Annual Research conference, Society for Sedimentary Geology (SEPM), 193-220.

PINDELL, J.L., KENNAN, L., MARESCH, W.V., STANEK, K.P., DRAPER, G. \& HIGGS, R. 2005. Plate kinematics and crustal dynamics of circum-Caribbean arc-continent interactions: tectonic controls on basin development in Proto-Caribbean margins. In: AVÉ LALLEMANT, H.G., SISSON, V.B. (eds) CaribbeanSouth American plate interactions, Venezuela. Geological Society of America, Special Paper, 394, 7-52.

POURTIER, E. 2001, Pétrologie et géochimie des unités magmatiques de la côte équatorienne: implications géodynamiques. Unpublished DEA thesis, University of Aix-Marseille, $35 \mathrm{pp}$. 
REYNAUD, C., JAILLARD, É., LAPIERRE, H., MAMBERTI, M. \& MASCLE, G.H. 1999. Oceanic plateau and island arcs of Southwestern Ecuador: their place in the geodynamic evolution of northwestern South America. Tectonophysics, 307, 235-254.

ROPERCH, P., MÉGARD, F., LAJ, C., MOURIER, T., CLUBE, T. \& NOBLET, C. 1987. Rotated oceanic blocks in Western Ecuador. Geophysical Research Letters, 14, 558-561.

SAMPER, A., MOLLEX, D. 2001. Pétrologie, minéralogie et géochimie des laves de la Cordillère occidentale équatorienne. Unpubl. Maîtrise Memoir, Univ. Grenoble I, 31 pp.

SANTOS, M. \& RAMIREZ, F. 1986. La Formación Apagua, una nueva unidad eocénica en la cordillera occidental ecuatoriana. Actas IV Congreso Ecuatoriano de Ingenieros en Geología, Minería y Petróleo, I, 179-190, Quito.

SANTOS, M., RAMIREZ, F., ALVARADO, G. \& SALGADO, S. 1986. Las calizas del Eoceno medio del occidente ecuatoriano y su paleogeografía. Actas IV Congreso Ecuatoriano de Ingenieros en Geología, Minería y Petróleo, I, 79-90, Quito.

SCOTESE, C.R., GAHAGAN, L.M. \& LARSON, R.L. 1988 Plate tectonic reconstructions of the Cretaceous and Cenozoic ocean basins. In: SCOTESE, C.R. \& SAGER, W.W. (eds), Mesozoic and Cenozoic Plate Reconstructions. Tectonophysics, 155, 27-48.

SINTON, C.W., DUNCAN, R.A., STOREY, M., LEWIS, J. \& ESTRADA, J.J. 1998. An oceanic flood basalt province within the Caribbean plate. Earth and Planetary Science Letters, 155, 221-235.

SPADEA, P. \& ESPINOSA, A., 1996. Petrology of late Cretaceous volcanic rocks from the southernmost segment of the Western Cordillera of Colombia (South America). Journal of South American Earth Sciences, 9 , 79-90.

SPIKINGS, R., WINKLER, W., SEWARD, D. \& HANDLER, R. 2001. Along-strike variations in the thermal and tectonic response of the continental Ecuadorian Andes to the collision with heterogeneous oceanic crust. Earth and Planetary Science Letters, 186, 57-73.

SPIKINGS, R., WINKLER, W., HUGHES, R.A. \& HANDLER, R. 2005. Thermochronology of allochtonous terranes in Ecuador : unraveling the accretionary and post-accretionary history of the Northern Andes. Tectonophysics, 399, 195-220.

STEINMANN, G. 1929. Geologie von Peru. Karl Winter publ., Heidelberg, 448 p.

SUN, S.S. \& McDONOUGH, W.F., 1989. Chemical and isotopic systematics of oceanic basalts: implications for mantle composition and processes. Geological Society, Special paper, 42, 313-345.

TAIPE, E., JAILLARD, E. \& JACAY, J. 2004. Estratigrafia y evolución sedimentológica de la serie del Cretáceo superior de la Península de Paita. Boletin de la Sociedad Geológica del Perú, 97, 7-27.

TORO, J. 2006. Enregistrement des surrections liées aux accrétions de terrains océaniques : Les sédiments crétacé-Paléogènes des Andes d'Equateur. PhD thesis University Grenoble 1, 425 pp.

TORO, J. \& JAILLARD, E. 2005. Provenance of the Upper Cretaceous to Upper Eocene clastic sediments of the Western Cordillera of Ecuador: Tectonic and geodynamic implications. Tectonophysics, 399, 279-292.

VALLEJO, C., SPIKINGS, R.A., LUZIEUX, L., WINKLER, W., CHEW, D. \& PAGE, L. 2006. The early interaction between the Caribbean Plateau and the NW South American Plate. Terra Nova, 18, 264-269.

VANMELLE, J. 2004. Arcs insulaires crétacés installés sur un plateau océanique crétacé inférieur à l'Ouest de l'Équateur : lithostratigraphie et caractérisation pétro-géochimique. Unpubl. maîtrise memoir, Univ. Grenoble I, $35 \mathrm{pp}$.

VANMELlE, J., VILEMA, W., FAURE-BRAC, B., ORDOÑEZ, M., LAPIERRE, H., JIMÉNEZ, N., JAILLARD, E. \& GARCÍA, M. 2008. Pre-accretion evolution of the Piñón oceanic terrane of SW Ecuador: Stratigraphy and geochemistry of the «Calentura Formation ». Bulletin de la Société Géologique de France, in press.

WALLRABE-ADAMS, H.-J. 1990. Petrology and geotectonic development of the Western Ecuadorian Andes: the Basic Igneous Complex. Tectonophysics, 185, 163-182.

WHITTAKER, J.E., 1988. Benthic Cenozoic Foraminifera from Ecuador. Taxonomy and distribution of smaller benthic Foraminifera from coastal Ecuador (late Oligocene-Late Pliocene). British Museum (Natural History) publ., 194 p., London. 